\title{
Research and Practice on the Work-integrated Learning of E-commerce Major in Higher Vocational Colleges
}

\author{
Wei Sun \\ Shaanxi Institute of International Trade \& Commerce, Xi'an, 712046, China
}

Keywords: Work-integrated learning, E-commerce major, Higher vocational colleges

\begin{abstract}
We have entered the internet era and the computer technology has been utterly ubiquitous. As a new business mode, e-commerce has become a trend in the internet era, which has affected all walks of life imperceptibly. However, the work-integrated learning of e-commerce major in higher vocational colleges in China has many problems, including ambiguous teaching objective, insufficient practice curriculum and low teachers' quality. In view of these problems, this paper puts forward the corresponding suggestions to provide some references for the relative researchers.
\end{abstract}

\section{Introduction}

The development of computer network technology in China has formed a relatively mature e-commerce environment, the market of e-commerce talent there is a huge vacuum, can foreknow, more and more companies began to try e-commerce business will be the future demand of domestic electronic commerce talents will continue to increase, but by contrast, many professional e-commerce people are facing employment difficulties, the training and positioning of electronic business specialty in Higher Vocational Colleges and students' ability of deviation strategy is not reasonable, need to continue to explore in the teaching practice, promoting teaching reform, cultivate the professional and technical personnel of social commerce post ability demand. The rapid development of computer technology makes our life more and more convenient. Now we can know the world from home, and can buy and sell goods by finger. With the development of computer technology, electronic commerce has become more and more mature, and China is in urgent need of professional talents in e-commerce. According to authoritative data, in recent years, there will be a large number of enterprises in China to apply e-commerce model to enterprise operation. The domestic electronic commerce talent gap will be bigger and bigger. Although e-commerce majors with a bright future, but the problem now is that there are a large number of e-commerce professional students cannot find a job, and the company is hard to recruit students employment of these two seemingly contradictory problems. In general, the gap between supply and demand is the cause of the difficult employment of students in electronic commerce. Higher vocational schools should formulate solutions actively, strengthen practice teaching, make occupation activities and teaching courses combine the teaching content and the social demand matched the teaching reform of higher vocational school is imminent.

\section{Cultivation Problems of of E-commerce Major in Higher Vocational Colleges}

Ambiguous Teaching Objective. At present, the curriculum system is based on the traditional theory on the subject, in the course of substance and enterprise job demand and not much correlation, so that the actual demand of talents and social culture that does not match. It also exists in the system of electronic commerce in higher professional settings, not only the combination of information technology and electronic commerce is very good, but also did not combine the curriculum system and enterprise job demand, resulting in Higher Vocational e-commerce graduates is not good employment situation. We do not link the professional training of e-commerce talents with the needs 
of enterprises in our country, and there is no clear division of Higher Vocational e-commerce talents training direction. The debate about the emphasis on technology and heavy business has never stopped in the setting of e-commerce major in higher vocational colleges, which makes the teachers have no clear training objectives, and the students' professional ability cannot achieve good results. It can be seen that the unclear goal of the training of e-commerce talents in higher vocational colleges will lead to the confusion of teachers' teaching objectives, and the students' professional ability cannot be improved. The development of information technology make the society more and more, the change of the social environment is becoming more and more quickly, whether it is on the upgrade of emerging enterprises, or traditional large enterprises are changing continuously with the social environment changes, not immutable and frozen business model. Vocational education is a training model based on employment indicators, which needs to strengthen the docking of practical teaching and theoretical knowledge.

Insufficient Practice Curriculum. As a new profession, professional school of electronic commerce many higher vocational colleges is not long, the lack of professional training experience, the continuation of traditional disciplines of education experience and the existence theory of partial light practice, lack of content setting practice core curriculum, students not in practical teaching activities in the master practical skills to understand the content of teaching. In addition, although many vocational colleges have noticed e-commerce professional requirements for practical ability, and in the teaching activities consciously add a variety of practical courses, such as curriculum design, operations, training week, production practice, internship and graduation practice, practice teaching occupies a considerable proportion in the total hours however, the e-commerce infrastructure such as school related practice base construction is relatively weak, the practice is formalized, it is hard to carry out, less cooperation opportunities, learning practice teaching quality is not high. E-commerce as an emerging industry in China, maturity is not high, pure e-commerce enterprises are rare, economically developed regions, to find suitable for the enterprise electronic commerce project feasibility is teaching practice of e-commerce, for some of the less developed areas for the electronic commerce project really is very difficult, the only study cases of famous enterprises students cannot really grasp, the electronic commerce project related procedures and practices, at the same time the enterprise internship positions is limited, and many enterprises for security considerations, the real core technology for students to contact to limit the effective use of students' practical teaching resources. Electronic commerce course is usually divided into professional basic courses and professional practice course, and now the vocational school will spend a lot of time in the electronic commerce based teaching, teaching in practice on the importance of practice courses in the curriculum is not high, the proportion is quite small.

Low Teachers' Quality. Electronic commerce is closely related to the use of teaching and substance. It has a high demand for teachers' professional quality and skill quality. At present, in the electronic commerce specialty of higher vocational education teachers in China, most of them are young teachers just graduated from school soon, their teaching experience is not enough, but also is not very understanding of the relevant circumstances e-commerce personnel training objectives and professional skills requirements. The insufficient part of e-commerce system of Higher Vocational Teachers' awareness of e-commerce, e-commerce and online shopping on the part of the vocational teachers and other aspects of the electronic commerce has no experience in teaching is to book knowledge verbatim in the classroom. Because the quality of teachers is not high, which greatly affects the development of e-commerce talents training in Higher Vocational colleges. The development of e-commerce can be described as the ability for occupation is change rapidly, increasingly high demands, but the current education idea lag, led to the current teaching materials are old and numerous loopholes, no study on the teaching materials and effective update did not keep pace with the times, the practice content and the actual content of the work does not match, did not achieve the effect of practice the teaching should have. Electronic commerce is a new business model, and now truly understand the electronic commerce talent mostly in the enterprise, so the higher vocational school lack of practical experience of the teachers, so in the teaching of electronic commerce theory knowledge, technical knowledge and practice content, teachers are not able to work 
in accordance with the actual requirements to guide students, resulting in lack of students practice ability.

\section{Suggestions on Work-integrated Learning of E-commerce Major in Higher Vocational Colleges}

Upgrade Teaching Concept. The construction of perfect e-commerce practice teaching system in higher vocational education is an important way of cultivating talents, "into the combination" concept into daily teaching, setting and development in the teaching course, cultivating students' professional practice ability is a priority task. Around the training courses teaching students occupation ability, organizational practice, increase students' practical opportunities, so as to effectively train students practice ability, improve the students' learning experience, enhance students' interest in learning. Electronic commerce as a new cross subject. It will be all aspects of computer information technology, modern logistics and business management are integrated: therefore, to students of electronic commerce professional training of senior specialized talents become a complex type, largely depends on the professional needs of school personnel and technology of e-commerce enterprises sure. Under normal circumstances, enterprises will be divided into electronic commerce professional technical positions and business positions and comprehensive management positions in three categories: the electronic commerce technical job includes platform design, website design and art design platform; business Post Internet marketing, online international trade; with the change of social environment, many outstanding professionals choose to stay in business, and even some leaders choose to start their own business. Comprehensive management positions of e-commerce platform and the comprehensive management of e-commerce enterprise comprehensive management part so the school can according to the enterprise to carry out targeted set different job categories of professional training objectives of the electronic commerce professional training needs. In addition, e-commerce students can also according to their own cultural literacy, professional foundation level and interest in learning and other practical conditions for their future study in the setting of long-term goals.

Increase Practice Curriculum. Reasonable reform of the curriculum system, change the previous emphasis on the theoretical guidance to set up the teaching mode of practical activities, the establishment of students' practical ability training as the focus of the teaching program. At the same time, the teaching plan should increase the practice course, let students have more time and opportunity to hone their skills in actual combat, to practice education theory re compiling new teaching materials, re organizing courses, professional e-commerce to establish a practice based theory of auxiliary teaching system. Practice teaching system should include basic theory teaching, practice teaching, teaching innovation, professional characteristics and professional teaching entrepreneurship courses, including the teaching contents of two basic e-commerce professional teaching system, curriculum and teaching practice is the comprehensive use of the theory. At the present stage of higher vocational school and enterprise cooperation is very common. Now the problem is that the level of cooperation between schools and enterprises is still relatively low, but only stay in the practice of cooperation, there is no long-term depth of cooperation plan. Students may only just like to cooperative enterprise internship for a period of time, not enough time to understand the situation of the industry, all these will lead to unsatisfactory effect of the electronic commerce teaching. In practice inside the school learning base construction is lagging behind the society, so the school should conform to the construction of personnel training teaching experimental site requirements, actively cooperate with enterprises to develop practice teaching, learning tutorials, which is advancing with the times in the content, can meet the needs of the society, so that students can have more opportunities to contact the electronic commerce actual project, the cultivation of students' practical ability. Outside the practice course should consider long-term cooperation with enterprises, and enterprises to achieve talent orientation quantitative training plan, truly form a multi win win-win mechanism for graduates to be able to obtain employment.

Enhance Teacher's Competence. The solution method is to feel as pressing danger vocational school can strengthen the teachers' practical skills training, so that teachers can have rich experience in the solid theoretical foundation of the conditions, the use of theory but also have a certain role in 
promoting. To cultivate high quality teaching team can implement the school enterprise cooperation mechanism, let the teacher into the electronic commerce enterprise contact line of work, personally attend to the construction of enterprise e-commerce project, let teachers accumulated valuable experience in actual combat. To strengthen the national relevant documents on the system reform of higher occupation education development learning. Only in this way can timely and accurately grasp the direction and requirements on the teaching reform of higher vocational education development of the country, can work in practice consciously in accordance with the direction of the country's reform and carry out the requirements of research, implementation and management. It is necessary to strengthen the study of educational teaching theory. Because the current teaching management in higher vocational colleges are not handsome fan graduated, they did not go through the systematic education teaching theory study, understand and grasp the properties, characteristics and regularity of the occupation education is not very accurate and thorough. We should strengthen the study of management theory. The management is a science, education and teaching management is a high technology content of science, only to strengthen the study of management theories, using the scientific theory to guide practice, in order to enhance the pertinence and effectiveness of teaching management, to improve the level and effect of teaching management: the four is to strengthen the management of teaching experience of the relevant institutions of learning. China's Higher Vocational Education in the process of reform and development, there are many colleges, especially the national demonstration colleges have good experience in education and teaching management, these good practices and experiences are worth learning and reference. Schools can also organize teachers to actively participate in the enterprise to participate in learning and practice, improve teachers' innovative ability, update the knowledge structure of teachers.

\section{Conclusion}

Electronic commerce major is a complex engineering system in combination with the construction of practical teaching system. It is a difficult teaching innovation, needing the e-commerce practice teaching innovation and practical teaching materials and optimization of teachers expanded and diversified combination of engineering practice teaching mode of innovative applications such as manpower, improve the employment situation of electronic students in higher vocational education.

\section{Acknowledgments}

This paper is the result of Research on Talent Cultivation Mode Reform of E-commerce Major in Higher Vocational Colleges with Work-Study Combination as the Breakthrough Point.

\section{References}

[1] Tan Yongping. Team Construction Strategy of Work-integrated Learning Mode in Higher Vocational Colleges Teaching Management [J]. Higher Education Forum, 2016(7): 79-82.

[2] Wang Jin, Tang Xin. Investigation and Research on the Present Situation of Work-integrated Learning of Five-year Higher Vocational Colleges and Universities: Taking Changzhou Technical Institute of Tourism \& Commerce as an Example [J]. Value Engineering, 2013(2): 277-279.

[3] Wang Shukun, Li Xueguang. Work-integrated Learning Mode in USA and UK Enlightenment on Outstanding-engineer Training in Our Country [J]. Education Teaching Forum, 2016(50): 6-7.

[4] Jiang Wen. Reform and Practice of '2+1'Project Orientation,Work-integrated Learning Talent Training Mode for Electronic Commerce Major in Vocational Colleges [J]. 2016(46): Education Teaching Forum, 2016(46): 245-246. 